\title{
PROPOSALS FOR RESOLVING LONG DUE FOREST OWNERSHIP CONFLICTS IN TURKEY (EASTERN BLACK SEA REGION CASE STUDY)
}

\author{
AYAZ, $H .^{*}-$ INANÇ, S. $^{2}$ \\ ${ }^{1}$ Faculty of Law Department of Public Law, Trabzon University, Trabzon, Turkey \\ ${ }^{2}$ Faculty of Forestry, Artvin Çoruh University, Artvin, Turkey \\ *Corresponding author \\ e-mail: hayaz@ktu.edu.tr; phone: +90-532-440-8691,+90-532-480-0207
}

(Received $2^{\text {nd }}$ Oct 2018; accepted $27^{\text {th }}$ Nov 2018)

\begin{abstract}
This paper discusses the principle causes of forest ownership conflicts and the alternative approaches to resolve them. The current forest legislation in Turkey primarily rejects the private forest ownership rights with very limited exceptions. At present, $99.9 \%$ of the country's forest is owned by the state. According to the results, the forest property subject to disputes in the Eastern Black Sea Region where the conflicts is most experienced is about $12 \%$ of the total forest area. Nearly half of the conflicted area includes the forests registered in the name of individuals in the past. The non-acceptance of private forest property and the nullification of the old-dated private forest property documents have caused both disappointment in people and damages to the forests. Within the scope of the research, land survey and assessments were carried out in the settlements of the Eastern Black Sea Region, and group meetings were held with the local people to determine the causes of the disagreements as well as the requests and expectations of the local people. In addition, the views and proposals of local forest engineers working as state officers in the region were investigated. The results were presented in tables and alternative recommendations were developed based on statistical evaluations. The results indicated that the existing legislation and practices were not considered appropriate by all the forest villagers interviewed and by $75 \%$ of the forest engineers working in the regional forestry administration. Legislative changes are inevitable to better protect the forests and minimize the conflicts. The legal property documents given to the people must be valid in forests subject to private property in the historical process. As a solution proposal, private forests located immediately adjacent to and integrated with state forests should be expropriated, but those intermingled within the agricultural and settlement areas should be left to private property provided that sustainability is maintained. The same solution proposal should be valid for the confiscated forests in the course of cadastral works conducted so far.
\end{abstract}

Keywords: forest cadastre and ownership, confiscation of forests, private forest ownership, forest protection

\section{Introduction}

The primary focus of the forest policy is to protect forest resources and meet social needs and expectations based on the sustainable management of forests. One of the obstacles to the protection of forests is the uncompleted forest cadastre works. As known, it is impossible to plan and sustainably manage forest resources with unknown ownership, size, location and boundaries. While Turkish forestry initiated planned forestry in the beginning of $20^{\text {th }}$ century, unfortunately the forest cadastral works have not been completed, and forest ownership problems have yet to be resolved. The forest area in Turkey is approximately $23,450,000$ ha. Cadastral works have been completed in about $80 \%$ of this forest area (GDF, 2016). However, because of the lack of respect for the actual property rights obtained by law in the past in forest areas where cadastral works have been completed, the cadastral process has led to intensive property disputes 
and thus forest resources and their sustainability were put under jeopardy. Moreover, cadastral works have often been halted in forest areas where traditionally used and appropriated by villagers.

This would be due to a number of reasons:

(i) Inability to establish a sound basis for forest ownership and frequent changes in ownership policy: In fact, forest ownership is a tool to serve to the purposes of forest policy and should be regulated to achieve the forest policy (Gümüş and Toksoy, 2001). However, Turkish forestry has not been based on such an infrastructure. The Ottoman Empire in the process of demolition has started to see forests as a source of income and manage them for this purpose since 1870. At the same time, the process of granting the rights to private property on the territory of the country has been initiated. In the process, although the transfer of state forests to the private property was banned, private property records also existed on state forests due to many inadequacies. In the first years of the Republic, settlements protruding into the forests continued, part of the forest land was registered in the name of individuals, and some areas were traditionally owned by the people. In the country, legislations acknowledging the forests as a national asset that should belong to the state and intervening the private forest ownership and traditional use have been accepted and implemented since 1937. Any kind of forests subject to private property were nationalized with the recognized legislation and $99.9 \%$ of forests were legally owned by the state (Ayaz and Gümüss, 2016).

(ii) The security of utilization and property rights on the forests is an important factor for long-term sustainability (McGinley et al., 2012): Various effects can arise from intervening ownership and the traditional utilization rights. On the one hand, careless exploitation and illegal tree cuts result in forest degradation (Webb et al., 2006; Yachkaschi et al., 2008); on the other, forests are converted to agricultural lands (Poudel et al., 2014) or people compete to get more shares from the resources, causing forests to deteriorate further (Asante et al., 2017). Nationalization of forests in Turkey has led to a significant amount of forest loss. While an average of 31,500 ha of forest area has been burned annually since 1937 (Bilgili, 1998), when official records on forestry began to be kept, approximately 290,000 ha of forest areas were intentionally burned by the public over two years immediately following the nationalization of all forests in 1945 (Çağlar, 1979). Today, a large number of property cases have been filed in courts in the course of sustainable forest cadastre studies. Ironically, people who cannot reach the desired result in the domestic law still continue to utilize the land and carry the cases to the European Court of Human Rights (ECHR). ECHR has concluded that in many of its resolutions, disproportionate interference was imposed on the right to property secured under Article 1 of the Additional Protocol to the Convention, resulting in the repatriation of the country (Ayaz and Inanç, 2009). On the other hand, however, some positive effects of state intervention on forest resources can also be seen. In Ukraine, for example, the majority of forests were in private ownership between 1796 and 1914 during which forest areas fell from 16.2 to $9.7 \%$. However, when forests became nationalized in the later period (1946-1996), the forests increased by about 3 million ha (Nijnik and Kooten, 2000). Furthermore, private forestry initiatives supported by the states in Europe, USA and Japan, where private forests have significant shares, have been successfully performed (Schmithüsen and Hirsch, 2010; Siry et al., 2005; Takahashi et al., 2017; Vangansbeke et al., 2015; Kvarda, 2004; Glück et al., 2010). 
(iii) Failure to maintain the completed forest cadastre over time: As a result of the cadastre, state-owned forests by law as well as unclassified forests in accordance with the laws are recorded as state property. While this is the case with official records, most of these forest lands $(76 \%)$ have continued to be used by former owners after the cadastre (Diktaş et al., 2017). The fact that areas traditionally used and appropriated by the villagers have been registered as state forests led to the halt of cadastral works in some localities due to the resistance of villagers, resulting in the incompletion of forest boundaries.

(iv) Compromising on illegal behaviors: Studies are underway to see the forests of the country as national asset and register the whole forests as a state property. However, since the 1950s, changes in forest laws have been made and the owned lands that are forests in nature according to universal acceptance were not legally considered as a forest and left to the ownership of people. Furthermore, the lands where the forest cover is destroyed, used for agriculture, collective settlement or animal grazing can be converted to non-forest status and sold out to the invaders, although they are owned by the state. These laws highly threaten forest resources and sustainability and encourage forest destruction.

The issue of forest ownership in the country is problematic due mainly to the legislative arrangements in the first years of the Ottoman Empire and the Republic. In fact, the land used in agriculture in the 1940s was sold to the public by the Treasury. In this process, some forests have been subject to sales even if it is contrary to the legislation. In the settlement units where the forest cadastre has still been carried out, all the lands which is determined to be forest before 1945 were registered as a state forest with all title deed records being invalidated. Moreover, there is no reimbursement for the forests purchased from the state with their cost.

The settlement of the dispute has not been resolved peacefully in order to minimize the infringement of the right. Instead, an approach contradicting the scientific notion was developed in a way that some parts of the forests that are in fact forest land according to international definitions were legally regarded as non-forest areas particularly from 1950 onwards. Thus, forestry legislation has been subject to numerous changes causing an increase in areas that are legally non-forested areas since 1950. Again, since 1970, the forest cover has been gradually destroyed and its land used for agriculture, pasture or collective settlement was taken out of the forest status and sold to the occupiers. As of the end of 2016, nearly 500,000 ha of forest areas were removed from the forest boundaries as their forest cover was illegally destroyed and some of which was sold to the occupiers (Çağlar, 1979).

Ironically, the laws in force encourage the destruction of forests. Specifically, a private forest property with a title deed is not accepted and these places are considered as state forests without paying their owners their costs. However, people who own the state forest areas by destroying them are able to buy those forest lands that they occupy without any justification. This situation has caused an intense reaction of former forest owners on the one hand and threatened the forest resources and their sustainability on the other.

Based on the long due forest ownership problems in the country, the purpose of this study is to enlighten the forest ownership issues over the history and provide proposals to resolve the problems of forest ownership encountered in Turkey by encouraging forest villagers to be a stakeholder and have consent in the process. The results of the study can provide significant contributions to the resolution of forest property problems. 


\section{Material and method}

\section{The case study area}

The case study area covers the provinces of Artvin, Bayburt, Giresun, Gümüşhane, Rize and Trabzon in the Eastern Black Sea Region. Nearly 3.3\% of Turkey's population lives in this region (TUIK, 2018). According to General Directorate of Forestry (GDF) records, the total area of the region is 3,870,000 ha, about $40 \%$ of which is forested (GDF, 2016). The region is the most challenging area of the country in terms of forest ownership issues that sparkled the motivations for selecting the areas as a case study site. To begin with, the case study region is primarily of rugged area with high slopes. Forests, agriculture and settlement areas are intermingled in the region which is subject to scattered settlements. This situation has led to the ownership of the forests surrounding agriculture and settlement areas by the local people. The forests around the villages are sometimes owned by land registry records which are obtained in any way, mostly based on the existence of occupation documents and actual use. The ownership problems in the region have reached to an extent that has caused the lack of performance of forest management planning and implementation processes, impeded forest cadastral works and again led to thousands of property cases to be filed and resolved in the courts. For example, a significant portion of the regional forests (e.g., $12 \%$ of the forests of the Maçka State Forest Industry) is excluded from forest management practices due to regional conflicts (social disputes) (Türker et al., 1999). There are some settlements where the forest cadastre has not been completed due to property conflicts in the region. Based on all these rationales, this area was selected for this research. The location of the case study area in Turkey is given in Figure 1.

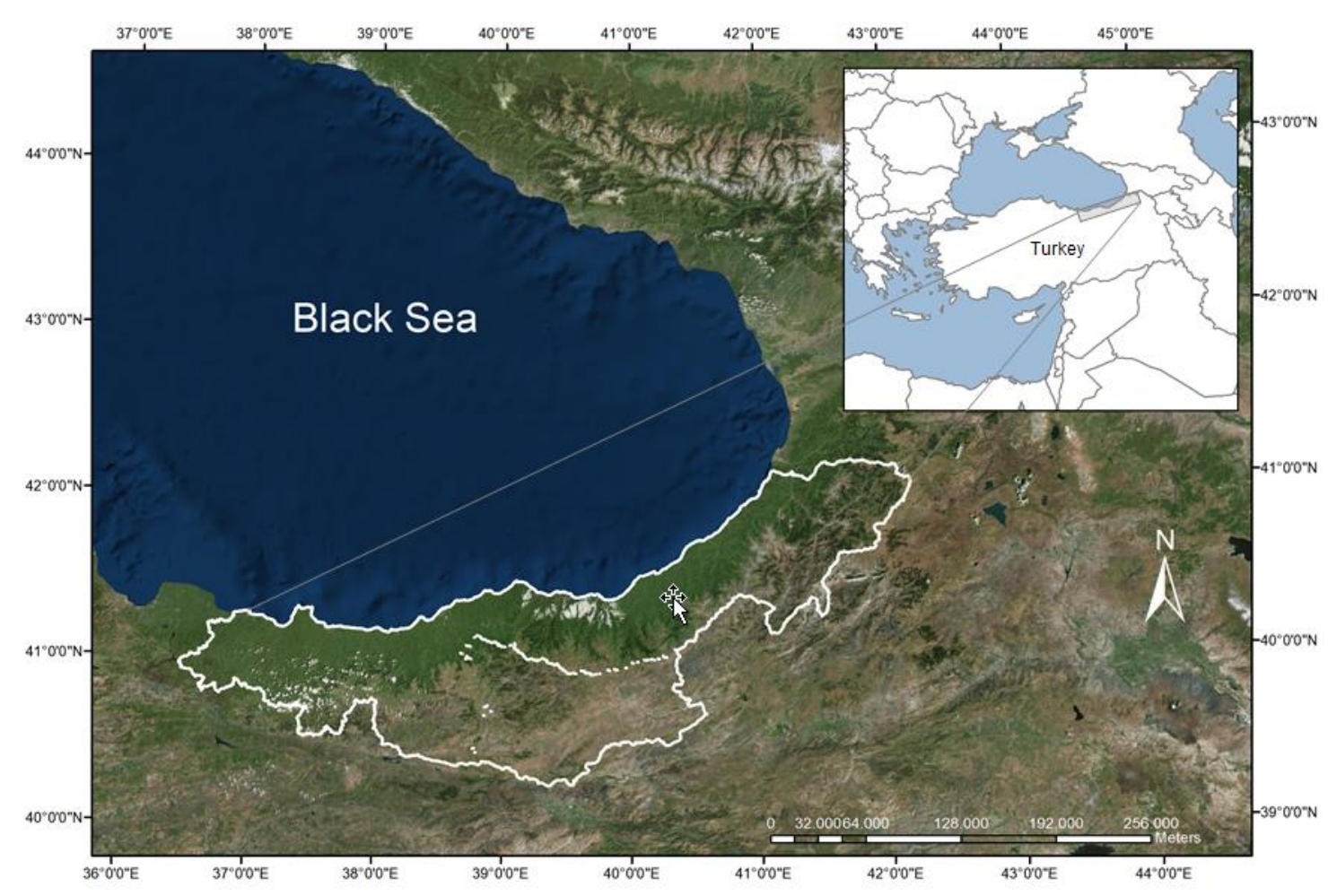

Figure 1. The location of the case study area in Turkey 
In the study, first of all, land cadastre records and forest cadastre documents which are primarily kept in forest administration were compiled. Thus, from 1937 onwards, settlement units with finished forest cadastre or forest boundaries established according to different legal arrangements were identified. Later on, information was collected from forest villagers and villages as part of the case study. For this purpose, two villages were selected from each province in the region. In selecting the settlements, the villages among all existing villages where the cadastre works have been established and had the highest number of court cases about property disputes were preferred. In the settlement where the cadastral works have yet to be completed, the forestry officers were interviewed and the sample ones among the villages encountering social conflicts during the implementation of forestry activities were selected. Table 1 shows the names of the villages subject to field survey and their spatial locations.

Table 1. The villages where field survey was conducted

\begin{tabular}{llll}
\hline Province & District & Village & Cadastral state \\
\hline \multirow{2}{*}{ Artvin } & Şavşat & Cevizli & Cadastre completed \\
& Ardanuç & Anaçlı & Cadastre completed \\
Bayburt & Merkez & Yoncalı & No forest boundaries \\
& Merkez & Armutlu & Cadastre completed \\
Giresun & Tirebolu & Belen & Cadastre completed \\
& Tirebolu & Yaraş & Cadastre completed \\
Gümüşhane & Center & Süle & No forest boundaries \\
& Center & Kurtoğlu & Cadastre completed \\
Ordu & Perşembe & Boğazcık & Cadastre completed \\
& Perşembe & Kazancilı & Cadastre completed \\
Rize & Pazar & Bucak & Cadastre completed \\
& Çamlıhemşin & Topluca & Cadastre completed \\
Trabzon & Tonya & Iskenderli & No forest boundaries \\
& Hayrat & Geçit & Cadastre not completed \\
\hline
\end{tabular}

The villagers in Table 1 have three distinctive characteristics in terms of cadastre. Forest and land cadastre were completed in 10 villages. The cadastre of the private property was completed in the remaining three villages and the cadastre of state land (forest, rangeland, treasury land etc.) was not completed. In Geçit village, no cadastral work has been conducted.

\section{Sampling method}

The second part of the survey is the development and implementation of questionnaire forms to the forest engineers who are the employees of General Directorate of Forestry in the Black Sea region. There are three regional forest directorates (RFD) in the region; namely Artvin, Giresun and Trabzon. A total of 324 forest engineers are employed in all three RFDs. In order to obtain statistical results, it is necessary to know the minimum number of samples. For this purpose, the number of sample size was calculated using a statistically acceptable $95 \%$ confidence level and $10 \%$ margin of error, assuming that the interviewees had completely different characteristics. According to these acceptances and values, the number of samples is calculated based on the Equation 1 as follows: 


$$
n=\frac{F \times t^{2} \times P \times Q}{\left(F \times m^{2}\right)+\left(t^{2} \times P \times Q\right)}
$$

$\mathrm{n}$ : Number of samples

F: Number of forest engineers

t: Confidence level (1.96 for $95 \%$ confidence level)

$\mathrm{m}$ : Error margin (taken as 10\%)

$\mathrm{P}$ and Q: Heterogeneity coefficient (-largest value - $0.5 \mathrm{X} 0.5$ )

According to the form, the number of forest engineers required to conduct the survey is 75. In the study, however, a questionnaire was applied to 171 forest engineers working in the region and evaluated. Thirty of the respondents were from Artvin, 66 from Giresun and 75 from Trabzon RFDs.

The identified 14 villages were visited under the scope of the case study and the headman and the villagers who experienced forest ownership problems were interviewed. The underlining reasons of the disputes about the forest status and its property were asked to the villagers during the interview. Some of the plots with conflicts were evaluated in the field. Additionally, some recommendations offered by the villagers about the proposals for resolving the problems were discussed. The questionnaire applied to the regional forest officers consists of 12 questions in total, including the personal characteristics of the respondents and the evaluations on forestry. With the six questions in the first section, the Regional Directorate of Forestry (RDF) that the participants work in; their age, gender, working time, post-graduate training and the position they hold were evaluated. The remaining six questions in the second part identified forestry problems and their views on the forest cadastre. The questionnaire form included blank fillings, multiple choice questions, grading and open-ended questions.

After the face-to-face interview for applying the questionnaire, the results were tabulated and the statistical analysis assessed with the SPSS program (Orhunbilge, 2000; Daşdemir, 2016). The hypothesis that there is no difference between the personal characteristics of interviewed forest engineers and their views and recommendations about forestry problems was tested. Chi-square test was used as a statistical method.

\section{Results}

\section{Interviews and investigations in forest villages}

After the regional problems related to the forest cadastre and ownership were compiled in the settlement units visited within the scope of the project, those with similar characteristics were brought together and divided into subsections. The main problems identified in this context are listed below, evaluated likewise and discussed in the sections that follow:

a. The land registry in the private forest properties is not honored and these places are regarded as state forests

b. The areas used for a long time or with tax-registered documents are also regarded as state forests

c. Historically non-forest areas that are naturally covered with forest vegetation as they have not been used in recent years are considered as state forests 
d. Different implementations are performed between neighboring settlements in determining forest boundaries

e. Some of the lands left outside the forest boundaries by the forest engineer in the cadastral commission is subject to the lawsuit by the forest engineers working in the state forest enterprise claiming that they are state forests

\section{a) No respect for land registry records in private forest properties}

It is possible to examine this problem in three aspects. The first one of these is the incompatibility of the size and borders of the title deeds with the realities on the ground. As explained introduction, large differences were observed between the amount of land registered and the amount of land owned based on this land register because the measurements were not carried out in the field at the beginning of granting the first title deeds in Ottoman Empire era and there were no maps, drafts and similar other documents to compare to. Sometimes an ownership right for over 50 decare $\left(50,000 \mathrm{~m}^{2}\right)$ areas was claimed based on just a one "Atik Dunam" (nearly $919 \mathrm{~m}^{2}$ ) with land title registration. As an extreme example, there is only one record in the old title deeds in Bucak Village of Pazar District in Rize Province with a registered area of one Atik Dunam yet the descriptions of the registration boundaries cover the whole village, settlement, agriculture and some forest areas. If this land register definition is respected, it must be assumed that houses belonging to other villagers, agricultural lands and state forests are to be regarded as a single property of a person.

Another problem about the land with old title deeds is the inapplicability of boundaries written on the title deeds to the ground. Specifically, it is impossible to find geographic features, as borders of the land property on the ground, such as border, ridge, creek, path, mountain, rock and a person name indicated in the narration of land registration record. In fact, there are many similar roads, creeks and lines in the same village used to differentiate from each other. Even the geographic directions of the boundaries of the described boundaries were not written in many title deeds. The problems encountered in the application of the title deeds about their amount and the boundaries can also be seen in the legislation. The Constitution and the Forest Law No: 6831 state that forests cannot be possessed with a long term use. The Item No: 20 of the Cadastral Law No: 3402 in effect stating as "If the boundaries stated in the records and documents that are not based on maps, plans and drawings are suitable for enlargement and changes, the amount indicated on the record is to be respected..." prohibits the determination of more areas during the cadastral process than the ones recorded in the registration. People holding the old title records are not pleased with these legal regulations.

Another problem experienced in the lands owned by the title deeds in the region is the "presence of a forest cover" on the land in 1945. According to the well-known Law No: 4785 dated 1945, which is still in force, the private property lands which were forests in 1945 or considered within the integrity of forests were all nationalized. The serious problem has been brought to today as the nationalization process was "performed without any action or notification". Ironically, there are still many land registry records for private persons for many properties under the scope of nationalization process according to the law. These records could or have not been abandoned because the amount of land subject to nationalization is unknown. Those who have inherited or registered their land registry record about the abovementioned land are still aware of their property which is also respected by their neighbors. In 
interviews with forest villagers, it was seen that the old title deeds were regarded as a very credible document and kept with care. In local terms, the "tribal/signed title deed" is seen as a strong evidence of the title deeds that contain the sign "tugra-the sultans signature" belonging to the sultan of the period. It is a great disappointment that the documents that are thought to be so strong, so long as they are old-dated, are not respected and the records are considered "invalid". Discussion of the amount and the boundaries of the title deeds and only respect for the written area on them are considered with tense reaction.

In the case study area, some of the remnant lands of the Greek emigrants, especially those who migrated through population exchange, were distributed to the Turks coming from Greece and given them the title deeds called an "exchange title deed". However, the immigrants in the country did not stay generally in the Eastern Black Sea Region and sold the land given to them in the local people and moved to the western parts of the country. The remaining agricultural lands from the Greek Cypriots were sold to the public by the Treasury. The title deeds given in this way are referred to as the "allotment title deed". The sizes of these places, which are purchased by paying to the state, are in general compatible with the amount indicated in the title deeds. Many of them have simple cadastral sketches. In the meantime, however, there are forests on some of these sold lands. Essentially, these type of lands sold by the state are regarded as "nationalized forests" by the law No: 4785 based on its famous Item stating that the private property lands which were forests in 1945 or considered within the integrity of forests are all subject to nationalization.

The people who had the old dated title deeds at hand, regard those lands as a kind of usurpation of the forests by the state they bought by paying installments until the middle of 1960s. Some people who are opposed to the application complain that "this law cannot be such an immoral practice imposed on citizens to see the revival of the state". The state sells the properties for 20 years in instalments and regards this land as a state property 2-5 years after the sale "without any action and notification". Paradoxically, there has been no actual field work on which land is to be nationalized since 1945 when nationalization process took place. Therefore, the location and the amount of nationalized land is unknown to anyone, including the state. In addition, the costs of the nationalized land sold to the public after the year 1945 were continued to be purchased in instalments. These lands with private property registration change hands by inheritance and subject to trade over the years. In one day over time, cadastral work is conducted and "this places are nationalized in 1945 as a state forest" and the records of title deeds are ignored retrospectively. It is quite difficult to explain this process with the rights and justice rules or procedures.

One of the cases of further disappointment is that in 1950 and later years, even the private properties with title deeds that were deemed to be based on the edited maps according to the Title Law No: 766 were regarded as state forests during the forest cadastre work. The justification of the lands as forests is that these places are identified and registered on behalf of individuals contrary to the law, even though it is prohibited to subject the state forests to private property in the Constitution and laws during the registration process of these lands. The forest administration states that the properties which are forests in nature are detected and registered illegally on behalf of individuals and for this reason the title deeds are deemed invalid due to the "corrupt registry" process. In anyhow, as a result of the forest cadastre, this land is regarded as a registered 
state forest, and since the place has been forest since way before, the property disputes carried to the courts also result in favor of the State.

It is too optimistic to expect landowners to accept this practice. As a matter of fact, forest property and ownership issues in the Eastern Black Sea Region have always been in the agenda. The majority of interviewees state that the state cannot take such an approach. Again, certain number of people think that the forest officers took over their land by changing the legal boundaries of the land. In other words, they are unable to reconcile this practice with the state law, or they think that cadastre employees apply a faulty and biased attitude. For that reason, local people show a hostile attitude towards the state forest officers and worse damage the forests.

The lands with title deeds were taken to the courts after its determination and registration as a state forest without giving any rights to its registered owners. However, judicial decisions resulting mostly in favor of forest administration (it has been determined that this ratio is more than $72 \%$ in a survey conducted in the region) cause people to hesitate to file a lawsuit. Since the lost side has to pay for the jurisdictional charges and the other party's proxy fee, not only do they lose the property of the case but also pay the due charges that shake the budget of the low income forestry village (Ayaz, 2004).

\section{b) Regarding the areas used over a long time or with tax-registered documents as state forests}

There are tax records that belong to some of the lands owned by individuals. These documents, which legally indicate the use right or possessions of the land, are perceived by the people as if they were documents of ownership. In fact, the local people have accepted the actual use situation of the land, and there is no significant conflict between the villagers. The people request that those land, whether forested or not, be identified on behalf of the occupiers of the areas subject to genuine actual use. In these records, there is a discrepancy between the borders in the field and the amount in the record, similar to the title deeds given in the Ottoman Empire period. Therefore, the fact that these records, which form the basis of the actual use over the forests, are not respected during the cadastre process causes the public to complain about.

On the other hand, the land that has been in private use for many years but with forest trees on is not identified and registered in the name of the user. This also negatively affects the cadastre. Besides, the $70 \%$ of individuals' ownership claims is based on the intellectual/use property during the cadastral studies in the region. The invalidity of the long term use rights in forest land is also an important factor in forest cover damages.

Some of the lands are registered as state forests based on a reason that they were forest before and were in integrity with the forests, although some agricultural practices were carried out on them. This situation was perceived by the villagers as an unjustified intervention. The people reacted to the process that the land stayed inactive over many years and the state has not intervened into the process of converting it into an agricultural field, and yet now claims that this area is a state forest after years and takes its ownership. The local people think of the fact that the state is unfair to them as the state gives some lands and houses free to the immigrants and refugees. 
c) Historically non-forest areas that are naturally covered with forest vegetation as they have not been used in recent years are considered as state forests

The rural and urban populations in Turkey have continued to increase over time. The rural population has intensively moved to the urban areas particularly after the middle of 1980s. The immigration has also included the forest villages. The population of the forest villages in the country were nearly 15 million around the 1970s that has dropped below 7 million since then (GDF, 2016). In the case study area, the population of the forest villages dropped by 43\% from 1970 to the end of 2007 (İnanç, 2010).

After migration from rural areas to the urban and developed areas, some of the land that was used for agriculture, rangeland or grassland was abandoned for itself. Forest vegetation has been developed over time with the contribution of the region's climatic conditions to growth trees on the unused lands. The places that the people had used as agriculture way before were determined as a state forest during the cadastre because they were covered with forest trees. The ownership in the land that was previously owned and constantly used without any controversy by the ancestors was also considered important in terms of the feeling of having "ancestor heirloom" by some people in addition to providing some material benefits. There are memories, encountered troubles and shared happiness in those lands. Sometimes there are stone walls, planted, grafted fruit trees that are woven around this area. As a matter of fact, during the visit of the villagers, it was determined that a pear tree exceeding 150 years old in a place where the meadow area and the forest area merged together in the Anaçli Village of Ardanuç District of Artvin Province and that a few spruce trees together at the same ages were located within the bounded areas as a state forest during the cadastre. The landowner complained that centuries-old fruit trees were not even taken into consideration during the cadastral period and that the land been used for centuries was regarded as a forest.

\section{d) Inconsistencies between different neighboring settlements in determining forest boundaries,}

Forest and land cadastre works started in 1939 in the region. However, factors such as tough land conditions, frequent legislative changes and often intervened forest and the non-forest use areas created problems in terms of the cadastral works. Completion of the cadastre in Turkey in an effort to join the European Union was targeted to be finalized particularly with subcontracting the private services. However, quick completion of the cadastre has not provided a solution, but rather triggered serious problems. For example, forest cover has begun to be destroyed in some areas in the region, in addition to filing numerous forest property lawsuits in the courts.

On the other hand, the definition of forests has been frequently changed by legislation in Turkey. Due to these changes, cadastral works have been implemented several times in the same settlement and different applications have been carried out by cadastral delegations who identify forest boundaries. There are some lands in different settlements that are in doubt to account them as forest or non-forest areas. While some cadastral delegations use the choice of forest, some do not regard the properties as a forest in this type of areas. The different applications are also recognized by the local people who complained about the inconsistencies and disparities. This situation was detailed in a study conducted by Ayaz in 2004 (Ayaz, 2004). 


\section{e) Some of the lands left outside the forest boundaries are subject to lawsuit}

The forest cadastre is conducted by commissions with a member of forest engineers. After the cadastral work has been completed, any natural or legal persons, as a legal right, can file a lawsuit with a claim that the boundaries of the forests have been determined illegally. Among those people are the state forest officials working in GDF. The ironical problem is that the forest boundaries determined by forest engineers working in the state forestry organization is subject to the case in a court by the other forest engineers working in the same state organization. Specifically, a unit in a state forest organization determines the draft boundaries of forest areas and the forest cadastre is carried out according to these boundaries. Afterwards, despite observing the limits of the forests, another unit in the state forest organization can also file a lawsuit for lands outside these boundaries. It is quite cumbersome trying to explain such an absurd situation or process.

One or several forest engineers working in the forestry organization determine the forest borders and other forest engineers again working in the same organizations reject the process afterwards. One of the most complained issues in negotiations with forest villagers is that the employees of the state forest institution have different opinions about the same land base, being forest or non-forest. In addition, the fact that the owners are asked to pay the costs of the judicial charges as well as the consequences of the lost case filed by the state forest officials against the land owners increased the complaints further. Fortunately, the law amendment in 2012 allowed the judicial remedy to be left for payment to the state administration who filed the case which eased a bit the victimization of the people to some extent.

The forest villagers interviewed in the field survey were asked what type of activity they would like to undertake in case they are given the forested areas they claim. Nearly all of the interviewed people stated that they consider it important because these areas have been owned by their ancestors since the beginning. People acknowledge that the claim of ownership has been ongoing for a long time, that these woodlands have a large number of shareholders and that it is unlikely to plan and manage this land. The local people also state that they want to meet their own fuelwood and construction needs freely from this forest. There are also some people who think that they can generate economic income by cutting and selling few trees. Importantly, it has been determined that the villagers do not have knowledge about the sustainable management of forest resources with a plan nor do they have any expectations towards that.

\section{Results of questionnaire applied to forest officers}

Forest engineers employed in GDF are directly associated with the problems caused by the conflicts in forest ownership. They conduct the forest cadastre works and are often exposed to an intense reaction by the local people. Most of the private properties are registered as state forest during the cadastral works according to the legislations in effect. Interestingly, nearly $70 \%$ of the forest engineers entitled to carry our cadastral works are from different provinces and their families are also adversely affected as a party in forest ownership conflicts. Thus, we tried to identify and evaluate the problems and the possible solutions brought by these forest engineers working within the complex cadastral situation.

The information about the participants such as the regional directorate of forestry employed, age, gender, post-graduate education, employment period and the unit of 
work were obtained in the questionnaire. It was also determined that $83 \%$ of the forest engineers working in the region were born in the same districts, and the elders of their family lived there. As seen in Table 2, approximately 59\% of forest engineers working in the region are under 35 years of age.

Table 2. Age of forest engineers in the region

\begin{tabular}{ccccc}
\hline Age & Frequency & Percent & Valid percent & Cumulative percent \\
\hline $0-35$ & 102 & 59.6 & 59.6 & 59.6 \\
$36-50$ & 54 & 31.6 & 31.6 & 91.2 \\
$51+$ & 15 & 8.8 & 8.8 & 100.0 \\
\hline TOTAL & $\mathbf{1 7 1}$ & $\mathbf{1 0 0 . 0}$ & $\mathbf{1 0 0 . 0}$ & \\
\hline
\end{tabular}

Approximately $32 \%$ of the engineers currently working are between the ages of 36 and 50 . Nearly $9 \%$ of respondents are aged over 51 years and $16 \%$ was female. The proportion of employed forest engineers who have received post-graduate training is around $8 \%$.

The duration of the employment or service was identified to determine the relationship between the working time of the respondents in the forestry organization and their perception on cadastre-ownership issues. According to the results, the average service period of the forest engineers working in Artvin RFD is 7 years, 11.5 years in Giresun RDF and 12.5 years in Trabzon RDF. The average service period is around 11 years when all the regions surveyed are included in the account (Table 3).

Table 3. The duration of employment of forest engineers

\begin{tabular}{cccc}
\hline RDF & Duration of employment (years) & Number of people & Std. Deviation \\
\hline Artvin & 7.30 & 30 & 6.007 \\
Giresun & 11.59 & 66 & 8.975 \\
Trabzon & 12.53 & 75 & 9.765 \\
\hline Average & $\mathbf{1 1 . 2 5}$ & $\mathbf{1 7 1}$ & $\mathbf{9 . 0 5 5}$ \\
\hline
\end{tabular}

It was decided to determine the current position of the interviewees during the interview. The main purpose here was to determine whether there is a difference in the perception of the forest cadastre problem and the task performed. As shown in Table 4, $29 \%$ of the interviewees are district forest managers and $32 \%$ of them "are engineers in various other branches". The rate of a forest engineer, who is the head or member of the forest cadastre commission, is about $9 \%$. Approximately $20 \%$ of the interviewees are working in the management team such as regional forest manager, assistant regional forest manager, state forest enterprise manager or assistant, branch manager.

\section{The assessment of employed forest engineers about forest stewardship, ownership and cadastre}

The information on forest engineers interviewed was compiled and their perceptions on forestry, forest property and cadastre were determined in the same questionnaire. The results obtained are presented in the following sub-sections. 
Table 4. The current position of the forest engineers interviewed

\begin{tabular}{lcccc}
\hline Job & Frequency & Percent & Valid percent & Cumulative percent \\
\hline District forest managers & 67 & 39.2 & 39.2 & 39.2 \\
Engineers in various other branches & 54 & 31.6 & 31.6 & 70.8 \\
Forest cadastre officer & 16 & 9.3 & 9.3 & 80.0 \\
Manager & 34 & 19.9 & 19.9 & 100.0 \\
\hline TOTAL & $\mathbf{1 7 1}$ & $\mathbf{1 0 0 . 0}$ & $\mathbf{1 0 0 . 0}$ & \\
\hline
\end{tabular}

Surveys were conducted to determine the opinions and solutions proposed by the forest engineers working in the region on forest property issues. Primarily, it was decided to determine the presence/absence and the level of the problem expressed as a general concept. Table 5 indicates that there are very few who extremely worry that there is an unmanageable problem and those who think there is no problem in the region's forestry. The percentage of those who say that the forestry of the region is not very different from other regions and that the current problems are ordinary is very high $(61 \%)$. Those who think that the problems are in a worse level than the other regions are considerably high $(37 \%)$.

Table 5. The views of forest engineers on forestry problems in the region

\begin{tabular}{lcccc}
\hline Problem detection & Frequency & Percent & $\begin{array}{c}\text { Valid } \\
\text { percent }\end{array}$ & $\begin{array}{c}\text { Cumulative } \\
\text { percent }\end{array}$ \\
\hline 1. No problem & 2 & 1.2 & 1.2 & 1.2 \\
2. There is a problem at the expected level & 104 & 60.8 & 60.8 & 62.0 \\
3. There are quite a few problems & 63 & 36.8 & 36.8 & 98.8 \\
4. There is a problem that can not be overcome & 2 & 1.2 & 1.2 & 100.0 \\
\hline TOTAL & $\mathbf{1 7 1}$ & $\mathbf{1 0 0 . 0}$ & $\mathbf{1 0 0 . 0}$ & \\
\hline
\end{tabular}

When the distribution of the results within the scope of the three regional forest directorates is examined separately, it is determined that Trabzon RDF employees participated in the "there are fairly more problems" opinion higher than Artvin RDF and Giresun RDF did.

Aside from the regular statistics, a deeper statistical analysis was conducted with Chi-square test. As such, the statistical differences between the personal characteristics of interviewed forest engineers and their views and recommendations about forestry problems were examined. The importance and the existence of cadastral and property problems among the forestry related problems experienced in the region were asked. The possible forestry problems were written for them and asked to rank these problems according to their importance. As clearly indicated in Table 6, about $65 \%$ of the forest engineers surveyed stated that the primary problem in the region was related to cadastre-ownership issues. This is rather an expected result as the most important current agenda in the political arena and the local media is the cadastral property.

One of the most important problems related to forestry in the region appeared to be the protection and sustainable management of forests (22\%). In fact, the forest cadastre is the main factor in endangering the sustainability of forests resources because intensive forest damages are frequently encountered with the expectation (fear) that 
their lands would be nationalized for forest due to cadastral works. It is therefore possible to relate this problem to the forest cadastre.

Among the forestry problems in the region, the first problem group including afforestation, wood production and forest-community relationships issues, which is considered to be important by us, appeared to be the low level of forestry-related problems. However, the result does not indicate that there is no problem in those challenging areas. The following provides a high level of participation in problem groups in the secondary or lower level as explained on the basis of the data.

Table 6. The list of the problems experienced in forestry activities according to the topics

\begin{tabular}{lcccc}
\hline \multicolumn{1}{c}{ Forestry issues } & Frequency & Percent & Valid percent & Cumulative percent \\
\hline Afforestation & 4 & 2.3 & 2.3 & 2.3 \\
Cadastre-ownership & 111 & 64.9 & 64.9 & 67.2 \\
Sustainable protection & 38 & 22.2 & 22.2 & 89.4 \\
Business administration & 8 & 4.7 & 4.7 & 94.2 \\
Forest-People Relations & 10 & 5.9 & 5.9 & 100.0 \\
\hline \multicolumn{1}{c}{ TOTAL } & $\mathbf{1 7 1}$ & $\mathbf{1 0 0 . 0}$ & $\mathbf{1 0 0 . 0}$ & \\
\hline
\end{tabular}

It is useful to put all of the options mentioned as problems in forestry together. In Table 7 the grading of forestry problems by the participants are shown together.

Table 7. Grading of problems experienced in forestry activities according to the issues

\begin{tabular}{lccccc}
\hline \multirow{2}{*}{ Forestry Issues } & \multicolumn{5}{c}{ Importance order (\%) } \\
\cline { 2 - 6 } & I. Degree & II. Degree & III. Degree & IV. Degree & V. Degree \\
\hline Afforestation & 2.3 & 15.2 & 21.6 & 24.6 & 35.7 \\
Cadastre-ownership & 64.9 & 18.7 & 9.9 & 5.8 & 0.6 \\
Sustainable protection & 22.2 & 37.4 & 22.2 & 13.5 & 4.7 \\
Business administration & 4.7 & 12.9 & 27.6 & 30.4 & 24.6 \\
Forest-people relations & 5.9 & 15.8 & 18.7 & 25.7 & 34.5 \\
\hline TOTAL & $\mathbf{1 0 0 . 0}$ & $\mathbf{1 0 0 . 0}$ & $\mathbf{1 0 0 . 0}$ & $\mathbf{1 0 0 . 0}$ & $\mathbf{1 0 0 . 0}$ \\
\hline
\end{tabular}

According to the respondents, the main problem in the field of forestry is the cadastre-ownership problem (Table 7). Approximately 65\% regards this problem in the first place and about $18 \%$ in the second level. In other words, the cadastral property issue appears to stay in the first two levels (83\%). The second most important problem in the field of forestry is expressed as the protection and sustainability of forests. Nearly $60 \%$ of the respondents see this problem in the top two levels. The third major problem in the forestry sector arises as forest-community relationships. Those who mark this option in the first two places have a total of $22 \%$. The management of forests including afforestation is not seen as a significant problem by the participants.

According to the results, the most important problem in the field of forestry was the "protection and sustainability" as prioritized it first by Artvin RDF employees statistically different from other RDFs $(\mathrm{p}=0.011)$. This problem was found to be more important than the others. In terms of the choice of the "people of the region", there are differences ( $p \leq 0.001)$ among the three RDF employees in assessing the sources of the 
problems of the forest cadastre and ownership. While Artvin RDF employees consider this issue to be important at $4^{\text {th }}$ level, Giresun RDF employees consider the issue to be important at $2^{\text {nd }}$ level. Unlike the others, Trabzon RDF employees consider the issue to be at $3^{\text {rd }}$ level and less important than the others. There is a significant difference among the RDFs $(\mathrm{p}=0.002)$ regarding the "contradiction of legislation to the expectations" option, one of the reasons of the forest ownership problem. Artvin and Giresun groups think that the effect of this option is less compared to the Trabzon group.

There was also a significant difference $(\mathrm{p}=0.031)$ in terms of the choice of "practitioner's inadequacy" among the causes of the current problem. Giresun RDF staff think that the "practitioner's inadequacy" is a more effective factor than other groups in their problems. Trabzon RDF employees are separated from other groups with the view that this factor is ineffective. Giresun RDF employees recognized this proposal significant at the first level and Artvin RDF employees considered it significant at the second level $(\mathrm{p} \leq 0.001)$. However, being different from the other RDFs, Trabzon RDF employees stated the proposal not to be implemented. On the other hand, Trabzon RDF employees significantly differ from the other groups $(\mathrm{p}=0.037)$ and consider the "the documents of old ownership should be recognized valid and these forests should be left in the status of private forest property" option.

The responses of the participants in the survey are tested to identify the differences in terms of sex. The results indicated that male participants were found to be statistically significant $(\mathrm{p}=0.014)$ from the other groups with the view that the "Legal confusion" option was effective on forest ownership. In addition, while female participants regarded the "Topographic conditions and land use pattern" option as one of the effective causes of the problem, male participants significantly differed $(p=0.015)$ from them and did not prefer this option to be effective. The "effect of changes in land use" due to out-migration was significantly different $(\mathrm{p}=0.009)$ by the women participants.

The effects of the age component on the problem were tested to see the difference in the evaluation of the problem. It was determined that the "topographic conditions and land use pattern" choice in the 0-35 age group and over 51 age group was not effective cause in the problem, differing significantly from the middle age group $(p=0.012)$. It has been found that the approach to the problem in terms of the duration of employment is significantly (.003) different from those of the others who have been working for 21 years or more. This group believes that the non-rule character of the people of the region is the cause of the problem.

There is a significant relationship between the employment period and "topographic conditions and land use pattern". The 0-10 age group employees differ from the others $(\mathrm{p}=0.040)$ and sees the option accelerating the problem further. Employees who worked for $0-10$ years and over 21 years significantly differ from others $(\mathrm{p}=0.010)$, accepting the idea that completed forest cadastre works "eases the forest management activities". As a solution of the problem, the option "Implementation without compromise according to current legislation" was primary accepted by the employees worked in short duration. However, this option was not adopted significantly $(\mathrm{p}=$ 0.010 ) as the duration of employees increased and listed at the bottom of alternative list. It was also found that employees over 11 years or more significantly $(p=0.024)$ adopted the view that the "old property documents should be considered valid and these forests should be left in the status of private forest". 


\section{Solution proposals for forest property and cadastre problems}

The results indicated that the forest property conflicts in the region are seen as a serious problem by the forest engineers working in the forest organization. In this section, opinions and suggestions regarding the source of the problems and their solution proposals are evaluated. The views and the perceptions about the source of the problem of forest ownership in the region are examined. The distribution of the answers given in order of preference in the questionnaire can be seen in Table 8.

Table 8 . The main causes of forest property conflicts

\begin{tabular}{lcccccc}
\hline \multirow{2}{*}{\multicolumn{1}{c}{ Causes of the problems }} & \multicolumn{5}{c}{ Importance level (\%) } \\
\cline { 2 - 7 } & $\begin{array}{c}\text { I. } \\
\text { degree }\end{array}$ & $\begin{array}{c}\text { II. } \\
\text { degree }\end{array}$ & $\begin{array}{c}\text { III. } \\
\text { degree }\end{array}$ & $\begin{array}{c}\text { IV. } \\
\text { degree }\end{array}$ & $\begin{array}{c}\text { V. } \\
\text { degree }\end{array}$ & $\begin{array}{c}\text { VI. } \\
\text { degree }\end{array}$ \\
\hline Local people & 9.4 & 9.4 & 15.2 & 17.5 & 22.2 & 26.3 \\
Legal confusion & 15.8 & 21.1 & 18.7 & 17.5 & 17.0 & 9.9 \\
Geographical conditions and land use pattern & 38.0 & 19.9 & 21.1 & 11.7 & 7.0 & 2.3 \\
Legislation violates expectations & 21.1 & 26.9 & 14.6 & 17.5 & 14.0 & 6.4 \\
Effect of change in land use & 11.7 & 15.8 & 16.4 & 18.7 & 19.9 & 17.0 \\
Inefficiency of practitioners & 4.1 & 7.0 & 14.0 & 17.0 & 19.9 & 38.0 \\
\hline TOTAL & $\mathbf{1 0 0 . 0}$ & $\mathbf{1 0 0 . 0}$ & $\mathbf{1 0 0 . 0}$ & $\mathbf{1 0 0 . 0}$ & $\mathbf{1 0 0 . 0}$ & $\mathbf{1 0 0 . 0}$ \\
\hline
\end{tabular}

Among the causes of problems in forest property and cadastre are the actual land use pattern and the topographic structure of the region. The forests in the immediate vicinity have been owned by individuals for many years due to the rugged formation of the region and the intermingled agro-settlement areas with forests. The current legislation sees these areas as illegal and rejects them. The second important reason is that the expectations of the local people were not met. In fact, the forestry legislation in the country was mainly prepared according to the socialist property concept in the 1930s. All forests were seen as state property with very few exceptions. Claims of ownership were often rejected by commissions that practice on behalf of the state and the courts generally decided against the individuals.

The second reason for conflicts in forest ownership was identified as legal confusion. Frequent changes in the legislation on forest cadastre and the property were seen in Turkey. In addition, there are also differences in the recognition of the rights to private property between forestry legislation and general laws such as civil law and the law of debts. Invalidation of old-dated property documents covering forests, the abrogation of property documents based on court decisions and again cancelation of property documents based on court decisions, when forest administration is absent, are all among the important reasons.

The third reason for current conflict is the frequent changes in land use pattern. This finding is based on two different implementations. The first one relates to the existence of previously forested lands yet their forest cover are destroyed and used as agriculture, settlement, pasture and so on. Because these lands are evaluated as forests in old documents (i.e., aerial photographs and topographic maps), they are determined as state forests based on old characteristics of land not the current uses. However, those who use this land illegally demand that their ownership be given to them. 
The change in land use is not limited to the destruction of forest areas and conversion to agriculture, settlement or other land uses. The rural population in Turkey has begun to decline particularly since the mid-1980s. As a result, animal breeding in natural lands has been reduced. The decrease in population and number of animals in the countryside resulted in the natural forestation of rangelands and agricultural lands. However, natural forestation of these lands, which were previously used for non-forest purposes, has emerged as a new problem. Since these areas do not generally have property documents like a certificate and mostly owned by the long term usage, they are regarded as a state forest during the cadastral process. This causes conflicts and triggers the reaction of the local people.

In the meantime, the negative attitudes of the people of the region and the inadequacies of practitioners are the least preferred options. The practitioners base the source of the problem on not themselves but on factors external to the people of the region.

Overall, the forest cadastre in the Eastern Black Sea Region was completed at a rate of $15-20 \%$ by the beginning of the year 2000. After this date, legislative amendments and arrangements for the coordination of the land cadastre and forest cadastre have facilitated the cadastral work to be accelerated. In the last 20 years, the realization rate of forest cadastre reached $80 \%$ level. Although this development seems to be encouraging, there is a doubt about the sustainability of the cadastre to solve the problems. The questions asked and the answers taken to determine the opinions of the respondents in this regard are given in Table 9.

Table 9 indicates that nearly $31 \%$ thinks that forest cadastre works have positive effects on the implementation of forest management activities. Those who think that the cadastre is not very effective, nevertheless still has benefits, are about $53 \%$. As a result, the overall impression about the importance of the forest cadastre reaches at about $84 \%$ rate. Of course, it would be desirable to implement forest management activities in the registered areas of forests. While there is no doubt about this, it is concerned that the conflict of ownership would cause destruction of forests and the lag of forestry activities.

Table 9. Assessment of whether forest cadastre is beneficial for forestry

\begin{tabular}{lcccc}
\hline \multicolumn{1}{c}{ The effects of forest cadastre } & Frequency & Percent & V. Percent & $\begin{array}{c}\text { Cumulative } \\
\text { percent }\end{array}$ \\
\hline Forestry work and operations are facilitated & 53 & 31.0 & 31.0 & 31.0 \\
Partial positive development in forestry studies & 90 & 52.6 & 52.6 & 83.6 \\
$\begin{array}{l}\text { There is no effect on forestry studies } \\
\text { It disrupts forest-community relations and negatively }\end{array}$ & 12 & 7.0 & 7.0 & 90.6 \\
affects forestry activities & 16 & 9.4 & 9.4 & 100.0 \\
\hline TOTAL & $\mathbf{1 7 1}$ & $\mathbf{1 0 0 . 0}$ & $\mathbf{1 0 0 . 0}$ & \\
\hline
\end{tabular}

About $7 \%$ thinks that forest cadastre has no positive effects on forestry activities. Those who think that the cadastral works carried out under the current legislation cause too much damages, rather than benefits, to the forests is about $9 \%$.

The opinions of the respondent forest engineers on the implementation of the existing system or the application of alternative methods in the forest cadastre and property determination works were investigated. Furthermore, continuation of the 
application of current legislation and alternatives about the change in different ways are also examined. In order to do this, a dialogue meeting was held with the employees in the forest organization in the region before determining alternative approaches that would not threaten forest existence and maintenance. Under this scope, five different alternatives were developed. It is decided to sort six alternatives according to their importance, together with the proposal of the continuation of current application. In addition, a free option is left for those who wish to express free opinions. The results are shown in Table 10.

Table 10. The proposed solutions by the forest engineers

\begin{tabular}{|c|c|c|c|c|c|c|}
\hline \multirow[b]{2}{*}{ Options } & \multicolumn{6}{|c|}{ Order of precedence $(\%)$} \\
\hline & $\begin{array}{c}\text { I. } \\
\text { Degree }\end{array}$ & $\begin{array}{c}\text { II. } \\
\text { Degree }\end{array}$ & $\begin{array}{c}\text { III. } \\
\text { Degree }\end{array}$ & $\begin{array}{c}\text { IV. } \\
\text { Degree }\end{array}$ & $\begin{array}{c}\text { V. } \\
\text { Degree }\end{array}$ & $\begin{array}{c}\text { VI. } \\
\text { Degree }\end{array}$ \\
\hline $\begin{array}{l}\text { a. According to the current legislation, } \\
\text { implementation must be carried out } \\
\text { without compromise }\end{array}$ & 25.7 & 7.0 & 8.8 & 4.7 & 13.5 & 40.4 \\
\hline $\begin{array}{l}\text { b. Ownership of state forests should } \\
\text { not be transferred but local } \\
\text { governments should be involved }\end{array}$ & 24.0 & 14.6 & 14.0 & 17.0 & 19.3 & 11.1 \\
\hline $\begin{array}{l}\text { c. The settlement-farming areas } \\
\text { should be allowed to be operated by } \\
\text { the local people in order to ensure } \\
\text { the continuity of the forests that are } \\
\text { intertwined }\end{array}$ & 11.7 & 26.9 & 21.1 & 21.6 & 12.9 & 5.8 \\
\hline $\begin{array}{l}\text { d. Those who belong to the forests that } \\
\text { are intertwined with the settlement- } \\
\text { agricultural areas should be left in } \\
\text { private ownership and measures } \\
\text { should be taken to ensure their } \\
\text { continuity }\end{array}$ & 19.3 & 17.5 & 21.1 & 19.3 & 17.0 & 5.8 \\
\hline $\begin{array}{l}\text { e. Old ownership documents should } \\
\text { be valid, these forests should be left } \\
\text { in the status of private forest }\end{array}$ & 15.2 & 20.5 & 13.5 & 22.2 & 15.8 & 12.9 \\
\hline \multirow[t]{2}{*}{$\begin{array}{l}\text { f. All owners, including possession, } \\
\text { should be admitted in the forests } \\
\text { formed with fast developing tree } \\
\text { species (alder for the region etc.), } \\
\text { and these areas should be } \\
\text { contributed to the continuation and } \\
\text { operation as forests }\end{array}$} & 4.1 & 13.5 & 21.6 & 15.2 & 21.6 & 24.0 \\
\hline & 100.0 & 100.0 & 100.0 & 100.0 & 100.0 & 100.0 \\
\hline
\end{tabular}

Approximately $26 \%$ of interviewed forest engineers expressed their opinion that forest cadastre should be conducted without any compromise according to the current legislation. The remaining $74 \%$ believe that a change in legislation on forest cadastre and ownership is necessary. In view of the preference for options proposed for legislative amendments, approximately $36 \%(24 \%+11.7 \%)$ agrees that the forests around the settlements should be managed by the local people in different forms providing opportunities for income, while remaining in state ownership. In places where settlements and agricultural areas are intertwined, about $19 \%$ of them desired the private 
ownership to be recognized according to old property documents. Regardless of the location of the territory, nearly $15 \%$ of the respondents recognize that the property documents of the people be considered valid and these places be given to their former owners during cadastre works. Only $4 \%$ of the respondents think that the private ownership of the land covered with fast-growing natural trees, including long term usage, should be given to its owners. Eventually, those who stated that private forest ownership should be recognized reaches $39 \%$ in total.

Significant $(\mathrm{p}=0.005)$ differences were found in terms of choosing the suggestions for the solution of the problem with the task being performed. While district management chiefs, cadastral unit employees and administrators, who are highly busy with intensive public relations, have expressed the opinion that the current legislation should be changed, the office workers favored primarily the view that the current legislation should be implemented without compromise.

\section{Discussion and conclusion}

Conflicts in forest cadastral works have continued since 1936 when the forest ownership work started on a regular basis in Turkey. The problem has not been solved, instead complicated further albeit the legal regulations introduced and implemented several times to solve these conflicts. The frequent amendments to the law do not make the people happy and threaten the sustainability of the forest resources. In the country, the deadlines are frequently renewed and the forests which are destroyed until that time (deadline) are sold to the invaders, or the private forest properties authorized by the cadastral works until the 1960s have not been regarded as forests and left in the hands of titleholders. It is necessary to change this course and introduce a new approach that does not threaten the existence and sustainability of the forest and takes into account the needs and expectations of the people.

Following the establishment of the Republic of Turkey from the mid-1930s until the 1990s, the common approach was that the forests were considered as national assets and thus not subject to private ownership. Furthermore, in this period, including the time of the Ottoman Empire in the country, the trend was that the private ownership of the forest areas was to be handed over to the state ownership as soon as possible (Diker, 1947; Bayrakraroglu, 1968; Caglar, 1979). Judicial units also adopted this basic approach until the early 2000s, and made the decisions to settle forest ownership disputes in favor of the state. In the meantime, however, it was also suggested that the problem of forest ownership could be solved by uncompromising implementation of existing laws and regulations (Eroğlu, 1999). Since the mid-1990s, various proposals and ideas have been expressed in a way that the needs and expectations of the forest villagers should be taken into consideration in forest management and ownership issues (Gümüss et al., 1998). Alternatively, another group of proposals suggested that certain parts of forests subject to private property should be left under private ownership providing that those forests should be protected and managed as forest resources (Gümüş, 1999; Ayaz, 2004; Meriç, 1999). However, there has been no change in the country's legislation regarding the handover of nationalized forests to their former owners. However, the legal definition of a forest has been changed causing some of the areas not to be considered as forest. The change of forest definition has also caused losses of over 1.2 million ha of forest from 1937 to 2005 due to the removal of degraded forest areas out of the forestry boundaries (Çağlar, Y., 2014). 
Approximately $12 \%$ of the forests in the case study area is claimed as a private ownership by the people of the region. Nearly half of these ownership claims (47\%) is based on cancelled title deeds, while the other part is based on long-term usage (Ayaz, 2004) Forests owned by individuals are mostly small pieces with less than one hectare. The people of the region will be happy if the laws are changed to return these forests to the former owners. Nevertheless, there is no willingness to ensure the sustainable management of these disputed forests. The problems experienced during the handover of forests to the former owners in the Balkan countries may likely be encountered in Turkey due to a number of reasons. These include the existence of small pieces of forests, the feeling that it is not worth trying because there will not be too much economic effect and the lack of expert member in forestry knowledge in family partnerships (Glück et al., 2010). It is unlikely that these forests will be managed efficiently by their owners. As a solution proposal, establishment of forest associations with the private forest owners and the creation of new management approaches are far away alternatives in Turkey (Vangansbeke et al., 2015; Takahashi et al., 2015).

Regarding the proposals of the forest engineers working in state forest organizations in the region, nearly $75 \%$ of them calls for an immediate need for legislative changes. Especially managers and the officers in the district forest units and forest cadastral commissions recommend the provision of private forest ownership in wider areas by going through the legislative amendments. Approximately $36 \%$ of the interviewed engineers expressed their view that the rules for the property in the legislation should not be changed frequently, but that the local communities would be granted more rights to benefit from these forest resources. There are also some researches suggesting the similar approaches (Koçak, 1999). 19\% of respondents agree that private ownership on the fragmented forests in residential areas is quite appropriate. Those who claim ownership of all forests in private property before any preliminary assessment have a $15 \%$ share, and the majority of this group has been employees more than 11 years. Only $4 \%$ of the respondents think that the forests dominated by fast-growing species such as alder must be subject to private ownership.

When the interviews conducted with the people of the region and the results of the surveys applied to the forest engineers in charge are evaluated together, it can be seen that the majority proposes changes in the current legislation. Otherwise, complaints of local people and forest destruction will continue. The forests in private properties are fragmented with small pieces that cannot be economically managed. In addition, some of the forests that are privately owned are intertwined with the state forests, which would create a serious problem in the future in terms of the integrity of these forests. On the other hand, however, the local people with the forest property do not have the required experience and tendency to manage the forests. There are also many heirs on the subject forests. Based on these ground, handing over the forests to the individuals as a private property would not seem to be an appropriate alternative in terms of forest protection and effective management of forest resources. The option of managing these forests by local governments is also not widely accepted by the parties.

Given the results of the research and the experiences assembled for many years, the problem may be resolved as followings. First of all, the endorsement of legal property documents given to the people in the historical process should be secured by the state particularly in forests subject to private property. Second, the privately owned forests that are integrated with the state forests should be registered as state forest for public benefit with the due costs paid to the owners. With this alternative, the forests would 
better be protected and managed in integrity and the former property owners will not be victimized because the costs of their properties will be paid for. Third, the fragmented forests intermingled with the agricultural areas and settlements may be returned to their former owners with the appropriate legislative changes as in the case of countries such as Poland and Ukraine, where the nationalized forest were returned to their owners (Nijnik and Kooten, 2000; Kvarda, 2004) provided that these forests are maintained as is. With this alternative solution proposal, the cadastre-ownership problem can be resolved peacefully without endangering the sustainability of these forests, which are estimated to have a size of $1 \%$ or $2 \%$ of the region's forest resources. In this way, any forest damages caused by the property disputes can be avoided and technically and scientifically recognized forest areas can also be legally recognized as forests providing legal security to these areas. The same solution proposal is also suggested for the confiscated forests in the course of cadastral works conducted so far. Finally, the results indicated that the existing legislation and practices were not considered appropriate by all the forest villagers interviewed and by $75 \%$ of the forest engineers working in the regional forestry administration. Thus, legislative changes are inevitable to better protect the forests and minimize the conflicts.

Acknowledgements. The authors thank, KTUBAP (Black Sea Technical University Scientific Research Found) for the financial support it provided to this project (Project Name: Effects of Forest Cadastre Applications in Eastern Black Sea Region and Alternative Approaches).

\section{REFERENCES}

[1] Asante, W. A., Acheampong, E., Boateng, K., Adda, J. (2017): The implications of land tenure and ownership regimes on sustainable mangrove management and conservation in two Ramsar sites in Ghana. - Forest Policy and Economics 85(1): 65-75.

[2] Ayaz, H. (2004): Turkey Implementation of Law No. 4785 A Study on Forestry and Results (Eastern Black Sea Region Example). - PhD Thesis, KTÜ Institute of Science and Technology, Trabzon, $170 \mathrm{pp}$.

[3] Ayaz, H., Gümüş, C. (2016): Forest property in Turkey experienced problems and proposed solutions. - KAREN Journal of the Institute of Black Sea Studies 2(2): 212236.

[4] Ayaz, H., İnanç, S. (2009): Private Forests in Turkey (Karadere-Kışlak Example). Congress Book on Socio-Economic Problems in Forestry. SDU, Isparta, pp. 55-64.

[5] Bayraktaroğlu, H. (1968): Provisions regarding forestry in the Turkish constitution and conditions for their evaluation. - Journal of the Faculty of Forestry Istanbul University, Series: B 18(2): 24.

[6] Bilgili, E. (1998): Forest fires and fire management policies in Turkey. - In proc. FAO

Meeting on Public Policies Affecting Forest Fires, FAO Forestry Paper No:138, p 357-362

[7] Bilmen, Ö. N. (1967): Law-i Islami and Istilahât-1 F1khiyye Kamusu. - Istanbul.

[8] Çağlar, Y. (1979): Forestry Policy in Turkey (Yesterday). - Çağlar Printing House, Ankara.

[9] Çağlar, Y. (2012): Turkey Forestry History. - ODTÜ Development Foundation Publishing and Communication AŞ, Ankara.

[10] Çağlar, Y. (2014): In Legal Gripper Forests and Forestry. - Union of Turkish Bar Associations, Ankara.

[11] Daşdemir, İ. (2016): Scientific Research Methods - ISBN:978-605-320-442-8, Nobel Akademik Yayıncılık ve Danışmanlık. 210 pp. 
[12] Diker, M. (1947): Forestry Yesterday-Today-Tomorrow in Turkey. - T. C. Ministry of Agriculture, GDF Publications, Ankara.

[13] Diktaş, N., Gümüş, C., Ayaz, H., Er, U., Sayın, M. A., Gerçek, V., Çolak, N. (2017): Partial Status of Forests and Partial Forest Management Problems (Trabzon Forest Management Directorate). - Research Project (Unpublished), Project No.: 03.8206/2013(2017): Eastern Black Sea Research Directorate, Trabzon.

[14] Eroğlu, M., Demirci, A. (1999): The Importance of Possibility Problem in the Continuity of Our Forest Assets and the Effect of Existing Practices on Solutions. - Proceedings of the Symposium on Problems of Forest Property in the Eastern Black Sea Region, 8-10 October 1999, Trabzon, pp. 91-99.

[15] GDF (2016): Forestry Statistics 2016.rar\ Forestry Statistics $2016 \backslash 10$ Forest cadastre _2016 - RAR Archive, Unpacked size 10.076.792 bayt. - Access: 07.06.2018.

[16] GDF (2016): Forestry Statistics 2016.rar \Forestry Statistics 2016\1 Forest Presence, 2015 - RAR Archive, Unpacked size 10.076.792 bayt. - Access: 07.06.2018.

[17] GDF (2016): Forestry Statistics 2016.rar\ Forestry Statistics 201617 Support for Forest Villagers_2016 - RAR Archive, Unpacked size 10.076.792 bayt. - Access: 07.06.2018.

[18] GDF (2016): Forestry Statistics, 2016. Forestry Statistics 2016 - RAR archive, unpacked size 10.076.792 bytes. - Access 02.07.2018.

[19] Glück, P., Avdibegović, M., Čabaravdić, A., Nonić. D., Petrović, N., Posavec, S., Stojanovska, M. (2010): The preconditions for the formation of private forest owners' interest associations in the Western Balkan Region. - Forest Policy and Economics 12(4): 250-263.

[20] Gümüş, C. (1999): Definition of Forest and Forest Regime in Turkey, Law No. 4785. Proceedings of the Symposium on Problems of Forest Property in the Eastern Black Sea Region, 8-10 October 1999, Trabzon, pp. 60-76.

[21] Gümüş, C., Ayaz, H., Bat1, M., Hacıhasanoğlu, S. (1998): Village Forestry Applications in Turkey. - Proceedings of the Forestry Symposium in the 75th Anniversary of Our Republic, 21-23 October 1998. Istanbul University Publication, Istanbul, pp. 68-77.

[22] Gümüş, C., Toksoy, D. (2001): Law No. 4785 over the Years 2000. - Turkey Foresters Association First National Forestry Congress, March 19-20. 2001. Foresters' Association of Turkey, Ankara, pp. 343-352.

[23] İnanç, S. (2010): Investigation of the Impacts of Population Movements on the Forest Presence in Rural Areas (Trabzon Regional Directorate of Forestry). - PhD Thesis, KTÜ Institute of Science and Technology, Trabzon.

[24] İstanbullu, T. (1978): It Belongs to Someone Else from the State Forest Administration and Operation in Turkey on Research. - İ. Ü. Forestry Faculty Publications, İstanbul.

[25] Kvarda, E. (2004): Non-agricultural forest owners' in Austria-a new type of forest ownership. - Forest Policy and Economics 6: 459-467.

[26] McGinley, K., Alvarado, R., Cubbage, F., Diaz, D., Donoso, P. J., Jacovine, L. A. G., de Silva, F. L., MacIntyre, C., Zalazar, E. M. (2012): Regulating the sustainability of forest management in the Americas: cross-country comparisons of forest legislation. - Forests 3: 467-505.

[27] Meriç, K. (1999): Forest, Property, Alder and Eastern Black Sea. - Proceedings of the Symposium on Problems of Forest Property in the Eastern Black Sea Region, 8-10 October 1999, Trabzon, pp. 234-242.

[28] Nijnik, M., Kooten, G. C. van (2000): Forestry in the Ukraine: the road ahead? - Forest Policy and Economics 1(2): 139-151.

[29] Orhunbilge, A. N. (2000): Sampling Methods and Hypothesis Testing (Review and Expanded Second Edition). - Avciol Printing and Publishing, İstanbul.

[30] Poudel, M., Thwaltes, R., Race, D., Dahal, G. R. (2014): REDD+ and community forestry: implications for local communities and forest management - a case study from Nepal. - International Forestry Review 16(1): 39-54. 
[31] Schmithüsen, F., Hirsch, F. (2010): Private Forest Ownership in Europe. - Geneva Timber and Forest Study Paper 26. United Nations Food and Agriculture Organization Economic Commission for Europe, Geneva.

[32] Siry, J. P., Cubbage, F. W., Ahmed, M. R. (2005): Sustainable forest management: global trends and opportunities. - Forest Policy and Economics 7: 551-561.

[33] Takahashi, T., Matsushita, K., de Jong, W. (2017): Factors affecting the creation of modern property ownership of forest commons in Japan: An examination of historical prefectural data. - Forest Policy and Economics 74: 62-70.

[34] TÜIK (2018): https://www. itspopulation.com. - Access: 07.06.2018.

[35] Türker, M. F., Balık, T., Ayaz, H. (1999): The Effects of Social Disputed Forest Areas on Forest Management Activities (Maçka State Forest Company Example). - Proceedings of the Symposium on Forest Property Problems in Eastern Black Sea Region, Trabzon, pp. 251-260.

[36] Vangansbeke, P., Gorissen, L., Nevens, F., Verheyen, K. (2015): Towards co-ownership in forest management: analysis of a pioneering case 'Bosland' (Flanders, Belgium) through transition lenses. - Forest Policy and Economics 50: 98-109.

[37] Webb, E. L., Shivakoti, G. P. (2006): Forest property rights under nationalized forest management in Bhutan, Sinagpore. - Environmental Conservation 33(2): 141-147.

[38] Yachkaschi, A., Adeli, K., Latifi, H., Mohammadi Samani, K., Seifollahian, M. (2008): Trends in Forest Ownership, Forest Resources Tenure and Institutional Arrangements: Are They Contributing to Better Forest Management and Poverty Reduction? A Case Study from the Islamic Republic of Iran. - Technical Report, FAO, Rome. 